\title{
Studying woodworking technology on ancient shipwrecks through digital photography and photogrammetry
}

\author{
Axel Eeckman \\ Archaeologist, alumnus Master MoMarch, Aix-Marseille University (AMU), Centre National de la Recherche \\ Scientifique (CNRS), Centre Camille Jullian (CCJ), Aix-en-Provence, France.
}

\begin{abstract}
Traceology is the discipline that studies anthropogenic, biological or use traces on any kind of material. This science through the study of wood used in shipbuilding offers the rare opportunity to study woodworking technology and so to apprehend the skills of past shipbuilders. Usually, traceology studies take place in laboratories, and only rarely are entire hulls or parts of them are extracted from the seabed. Therefore, a methodology for in situ documentation of woodworking was designed and applied to two Croatian shipwrecks: the Bronze Age shipwreck of Zambratija and the Roman barge of Kamensko.
\end{abstract}

\section{Key words}

Photogrammetry, shipwreck, traceology, toolmarks, wood, woodworking technology.

\section{Introduction}

This paper is the result of my master dissertation (Eeckman, 2017), which was presented in 2017 at the end of two years of studies for the Master of Maritime and Coastal Archaeology (MoMArch) at the Aix-Marseille University (France). The aim of my research, which was directed by Giulia Boetto and supported by the Centre Camille Jullian, was to investigate the role of traceology (a branch of archaeodendrometry) in nautical 
archaeology. My participation in the 2016 excavation of the Roman barge of Kamensko (Kupa river) gave me the opportunity to document the bottom photographically. This allowed the direct examination of the remains and the generation of a precise 3D model of the excavated part of the bottom planking. In addition, I was able also to examine the photographs of the Bronze Age Zambratija shipwreck and two fragments of planks retrieved from the seabed during the 2013 campaign. Thus, I was able to compare the different methods for the study of woodworking traces. This research was conducted in the framework of the research program ADRIBOATS led by Giulia Boetto and intended to study the ancient shipbuilding traditions in the eastern Adriatic.

\section{The role of traceology in nautical archaeology}

Ships are the most technologically advanced machines of any past culture (Muckelroy, 1978: 226-228) and traceology is a fundamental aspect of any nautical archaeology study since it allows us to understand the philosophy behind the construction of these complex machines, particularly when written sources are absent. More specifically, it permits characterisation of the principles and methods of shipbuilding, as illustrated in two Mediterranean examples. In the first, Honor Frost and William Johnstone noticed in 1973 several incised and painted marks on the Marsala Punic ship hull. These marks established the order of operations that the shipbuilders followed (Frost, 1973: 44). The study of Eric Rieth on the Culip VI wreck (13th-14th c. AD) is also worth mentioning. On this shipwreck, two different types of marks were discovered. Those of first type were Roman numerals intended to organize the order of fastening of every piece (Rieth, 1998: 206-207). The second type consisted of simple patterns, a method utilised in the oldest conception of shipbuilding: the patterns (Rieth, 1996: 62-64).

Sometime, traceology helps in narrowing down, or even pinpointing a possible construction origin. In the case of the Marsala Punic ship, the palaeographic study of the marks helped to date the ship around 300-250 BC. What is more, the study of the letters' shapes suggested that the shipyard was situated in the central or western Mediterranean (Frost, 1981: 238). In some cases, shipyards can be precisely identified. Béat Arnold studied several planks discovered in Avenches/En Chaplix (Switzerland) and dated them to the $1 \mathrm{st}-2$ nd $\mathrm{c}$. AD (Bonnet, 1992). Their dimensions and the toolmarks were comparable to those present on the Bevaix vessel found in the Neuchâtel lake. This observation, coupled with the discovery of several woodworking tools, suggested to Arnold (2009: 167-172) that these planks were meant for the construction of a boat and that the site could be identified as a boatyard.

Traceology also helps us understand economic behaviours. The results of the traceology study of the Hedeby 2 shipwreck were compared to another wreck from the same nautical area, and the lack of traces of use showed that the first one was in fact an unfinished boat. This discovery highlighted an industrial practice during the Viking age where the boats were pre-shaped, and finished at a later time (Crumlin-Pedersen, 1997: 150-155). Based on the benefits of traceology in nautical archaeology, I studied the two Croatian shipwrecks. The following pages will mainly focus on the technical aspect of the methodology I used.

\section{The first case of study: the Zambratija shipwreck}




\section{Background of the Zambratija shipwreck}

The Zambratija shipwreck was discovered in the Bay of Zambratija, north of Umag in Istria (Fig. 1). It is the oldest preserved fully sewn boat in the Mediterranean, and probably the first example of the north-eastern sewnboat shipbuilding tradition (Boetto, 2016; Pomey and Boetto, 2019). Laying at a depth of $2.5 \mathrm{~m}$, the shipwreck was investigated since 2008 and the last excavation campaign took place in 2013 through collaboration between the Archaeology Museum of Istria and the Centre Camille Jullian (Fig. 2). Built from a single log (P2) that worked as a proto-keel to which several planks where attached, the boat was around $9 \mathrm{~m}$ long. Three frames were found, lashed by external lashing (not conserved) to the hull (Boetto 2016; Koncani Uhač et al., 2017: 2935) (Fig. 3).

\section{Traceology study of the Zambratija}

The traceology study of the Zambratija boat was based on photographs taken during the 2013 excavation campaign by Philippe Groscaux, photographer of the Centre Camille Jullian at the time (Eeckman, forthcoming). The goal was therefore to highlight the practicality of traceology examinations through photographs when there is no access to the physical remains. Some elements were visible at first sight, such as the tree rings on the front of the keel-plank P2 (Fig. 4), or the axe marks on the inner surface of it (Fig. 5). However, working exclusively from photographs posed one main problem: the shots were taken to record the shipwreck generally, thus not capturing in detail the wood's morphology or the toolmarks. Consequently, these details were subjected to distortion, since the shots were not taken parallel to the timber, and the illumination was insufficient. To correct this issue, I modified the contrast and luminosity of the pictures using Photoshop. All in all, only detailed, high quality photographs can help the study of tool and use marks (Fig. 6 and Fig. 7). However, they do not replace direct observation. When the remains can be studied in situ, the expert in traceology is able to observe the trace from different angles and can also touch the surface of the material so as to feel all micro reliefs, which are sometimes invisible to the eyes.

Because of the difficulties of traditional photography through the example of the Zambratija shipwreck, we created a protocol based on photogrammetry. Its efficiency was tested on the Kamensko shipwreck, as explained in the following section.

\section{The second case of study: the Kamensko shipwreck}

\section{Background of the shipwreck of Kamensko}

The shipwreck of Kamensko was discovered in the Kupa River, not far from the city of Karlovac (Fig. 1). It corresponds to a flat-bottomed barge from the 2 nd -3 rd $c$. AD that carried a brick cargo when it sank. The hull was also characterised by the use of metallic clamps to fasten the strakes, a construction feature observed on a specific shipbuilding tradition of the Danube River hydrographical basin (Boetto 2016; Divic, 2016: 69-78; Pomey and Boetto, 2019) (Fig. 8). After the recovery of the brick cargo in the 2016 trench, and under the dunnage composed of branches, the hull was finally exposed, presenting many well-preserved toolmarks (Fig. 9). This discovery led us to build an experimental protocol of data acquisition, in order to overcome the difficulties of a traceology study using only photography, plus allowing us to leave the ship's remains in situ. 
This experimental protocol would not have existed without the help of Vincent Dumas, topographer and expert in photogrammetry, and Loïc Damelet, who took the shots underwater, both from the Centre Camille Jullian.

\section{Methodology and the experimental protocol}

First, each toolmark that was sufficiently well-preserved to be studied was located, measured, drawn by hand and further compared to photographs. Another step consisted of doing a photogrammetric survey of all microreliefs left by tools or due to the use of the barge, and comparing the results with the records made previously. As opposed to the case of Zambratija, the pictures here were taken with the precise purpose of studying the marks on the wood. To that end, we began positioning every mark with pins, but this method proved to be too time consuming and it polluted the data processing. Instead, we decided to do classical photogrammetry, but to repeat the process with three different cameras (ideally, the pictures should be taken by the same person) to compare the results from one to the others. By generating a photogrammetric model we were ensuring the creation of a document reproducing the real dimensions of the traces, with minimal distortion, and with altimetric information in the coding of the pixels. As opposed to simple photographs, photogrammetry gave us advantages comparable to direct visual observations, and surpasses the concept of a simple illustration. All photographs were captured at a distance between $10 \mathrm{~cm}$ and $80 \mathrm{~cm}$ from the hull, depending upon the size of the toolmarks and always including strategically-placed targets to maximise precision. A Nikon D700 camera, a Canon PowerShot SX210 IS and a GoPro Hero 3 were the cameras used to that end. The first one gave the best results, since it was the only camera to create RAW files. The other two cameras recorded the pictures in JPEG files, which means that the colorimetric data is modelled by flat colours, and so the micro-marks are not visible, making traceology studies impossible to achieve.

Parallel to this, a digital model was generated, aiming to highlight other traces that were not brought to light by the previous methods. In fact, digital models are usable through GIS programs, which is designed to deal with relief.

The experimental protocol was tested on strake P4. A target was placed on the keelson near P4 and used as a reference point to take the pictures of the strake. However, the keelson was higher and had a different inclination angle than $\mathrm{P}$, which proved to be problematic, since GIS programs need a projection system defined by a plane and a scale to work on any digital model. In this case, P4 and the keelson were located on different planes, and the GIS software could not exploit the data (Fig. 10). To succeed we had to assign P4 its own projection plane. Even though the experimental protocol had certain limits, we succeeded in creating both a digital model and an orthophotograph with a pixel error equal to $0.0338 \mathrm{~mm}$ (Fig. 10). The goal of making two different models of P4 was to overlay and compare them, since they have the same spatial references. What is more, it solved the problem of the lack of scale on the digital model. Considering these limits, future photographic acquisitions should be made with one smaller target for every different plane on the shipwreck.

Once the digital model of P4 was finished, the aim was to highlight toolmarks with the help of digital filters, a technique similar to the one used by S. A. Semenov with light filters. Semenov (1964: 24-26) highlighted the marks of use and shaping on flint tools by modifying the spectrum of the light. To achieve this, we first attempted to change the colorimetric values of the digital model. As a result, a different colour range classified each 
altimetric value of the digital model (Fig. 11a). These values fluctuated between minus $7.716 \mathrm{~mm}$ and 21.424 $\mathrm{mm}$, and represented the thickness of the strake P4 that was exposed $(1.3 \mathrm{~cm})$. Then, each colour range was measured at 5 micrometer intervals to allow a clearer observation of the toolmarks.

On this first attempt, we managed to stress out the altimetric information in the digital model. On a second attempt, we assigned $1 \mathrm{~mm}$ lines to the digital model to create an altimetric mapping of the toolmarks (Fig. 11b). The results were satisfactory concerning the contouring of the clamps and pins, yet we looked for a better definition of the toolmark lines. During a third attempt, we focused on the inclination of each micro relief, and as a result we identified very precisely the limits of the strake, the clamps used to fasten the strakes, and the plastic pins placed by archaeologists during the excavation (Fig. 11c). Furthermore, the characterisation of the traces was more efficient and we were able to identify axe and adze marks. The final attempt was carried out by modifying the illumination of P4 vertically and horizontally, which created shadows on the strake and enabled us to identify every trace as if we were studying the wood in a laboratory (Fig. 11d).

This research, paired with direct observations, indicated that the strakes were cut with the help of two different axes and that strokes were oriented from ends of the plank to its middle. The presence of faint adze marks showed that this tool was used exclusively for the finishing stages. Lastly, a chisel was used to fashion the clamps' holes.

\section{Conclusions}

As quickly pointed out in the first section of this paper, traceology plays an important role within the study of ship and boat woodworking. In addition to complementing traditional methods, traceology enables the evaluation of a society's technological development. In nautical archaeology, traceology allows us to collect important data and characterise principles and methods of shipbuilding, and to attempt to identify shipyards and to understand some economic aspects of certain cultures.

On the other hand, this paper intended to present the potential of a traceology analysis through photography. As proven by the example of Zambratija, a traceology study needs to be led by a specialist during the excavation, both to carry out the preliminary identification of the traces and to guide the documentation methodology by adapting the methods to the specific situation. This is why, during the excavations at Kamensko, we developed a protocol of data acquisition that enabled us to gain in efficiency. The protocol consisted on building a highquality photogrammetric model, to then create a digital wood surface model. By applying different digital filters to that model, we were able to identify and classify all micro reliefs with precision.

Consequently, the previously described results are promising. Even if a traceology study is demanding, time consuming and requires the presence of a specialist on the field, it certainly enriches the results that can be obtained through the post-excavation research phase.

\section{Acknowledgements}

I would like to acknowledge the director of the said dissertation and co-director of the excavations at Zambratija and Kamensko, Giulia Boetto, for her availability, her wise advices and guidance. My thankfulness goes as well 
to my closest collaborators in this work, Vincent Dumas and Loïc Damelet. I also acknowledge here my partner and first reviewer, Maria Soledad Blaco Nuñez, as well as my close friend John Mac Daid for his help.

This work would obviously not exist without the great works of Ida Koncani Uhač and Marco Uhač, co-directors of the excavation at Zambratija, and Krunoslav Žubić, co-director of the excavation of Kamensko. I also acknowledge all experts who participated to these excavations, and especially my colleague Alba Ferreira Dominguez, Anton Divić and Alex Sabastia.

Finally, the publication of this report would not have been possible without the tireless work of the organisers of the Maritime Archaeology Graduate Symposium, Maria Michael, Naseem Raad, and Ziad Morsy.

\section{Reference List}

Arnold, B., 2009, A gallo-roman building yard at Avenches/En Chaplix, in R. Bockius(ed.), Between the seas: transfer and exchange in nautical technology, Proceedings of the Eleventh International Symposium on Boat and Ship Archaeology (ISBSA 11), Mainz 2006, 167-172. Mainz.

Boetto, G., 2016, Recherches d'archéologie navale en Adriatique orientale. Comptes Rendus de l'Académie des Inscriptions et Belles-Lettres, 1401-1422.

Bonnet, F., 1982, Le canal romain d'Avenches, Rapport sur les fouilles exécutées en 1980 et 1981. Bulletin de l'Association Pro Aventico. 27, 5-52.

Crumlin-Pedersen, O., 1997, Viking-Age ships and shipbuilding in Hedeby/Haithabu and Schleswig. Schleswig and Roskilde.

Divić, A., 2016, A Roman barge from the river Kupa at Kamensko (Croatia): the preliminary study of its architecture in the context of Southeast European bottom-based naval construction. Unpublished Master Thesis. Aix Marseille University, Aix-en-Provence.

Eeckman, A., 2017, La tracéologie et le bois dans l'archéologie navale. Recherche à travers différents outils informatiques. Unpublished Master Thesis. Aix Marseille University, Aix-en-Provence.

Eeckman, A., forthcoming, A preliminary study of tool marks seen of the Zambratija wreck, in I. Koncani Uhač, G. Boetto and M. Uhač (eds), Zambratija. Prapovijesni šivani brod / Prehistoric sewn boat. Pula.

Frost, H., 1973, First season of excavation on the Punic wreck in Sicily. The International Journal of Nautical Archaeology 2, 33-49.

Frost, H., 1981, Lilybaeum (Marsala) - The Punic Ship: Final Excavation Report, Roma: Notizie degli Scavi di Antichità 30.

Koncani Uhač, I. et al., 2017, Zambratija. Prapovijesni šivani brod/Prehistoric sewn boat/Una barca preistorica/Un bateau cousu préhistorique. Pula: Katalog 85.

Muckelroy, K., 1978, Maritime Archaeology, Cambridge.

Pomey, P. and Boetto, G., 2019 Ancient Mediterranean Sewn-Boat Traditions. The International Journal of Nautical Archaeology 48.1, 5-51.

Rieth, É., 1996, Le maître-gabarit, la tablette et le trébuchet :essai sur la conception non-graphique des carènes du Moyen âge au XXe siècle, Paris. 
Rieth, É., 1998, L'épave du caboteur de Culip VI (Catalogne, Espagne): un témoignage du début du XIVe siècle d'une conception reposant sur la méthode du maître-gabarit et de la tablette, in P. Pomey and É. Rieth (eds), Construction navale, maritime et fluviale: approaches archéologique, historique et ethnologique, Proceedings of the Seventh International Symposium on Boat and ship Archaeology, Tatihou 1994, 205-212. Paris: Archaeonautica 14.

Semenov, S., 1964, Prehistoric technology: an experimental study of the oldest tools and artefacts from traces of manufacture and wear, London.

\section{Figures}

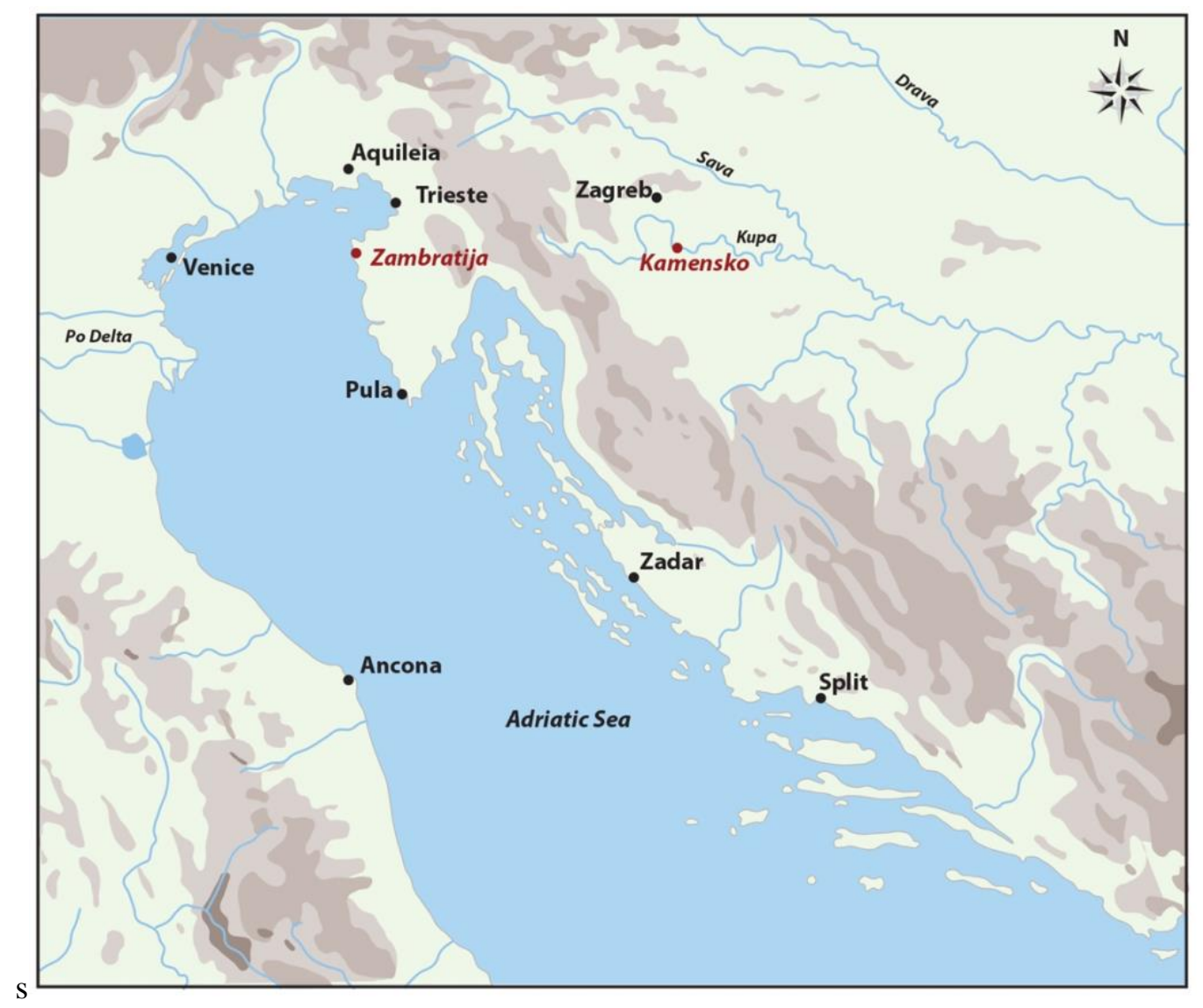

Fig. 1: Localization of the Zambratija and Kamensko shipwrecks. (@V. Dumas and G. Boetto, 2019. AMU/CNRS/CCJ). 


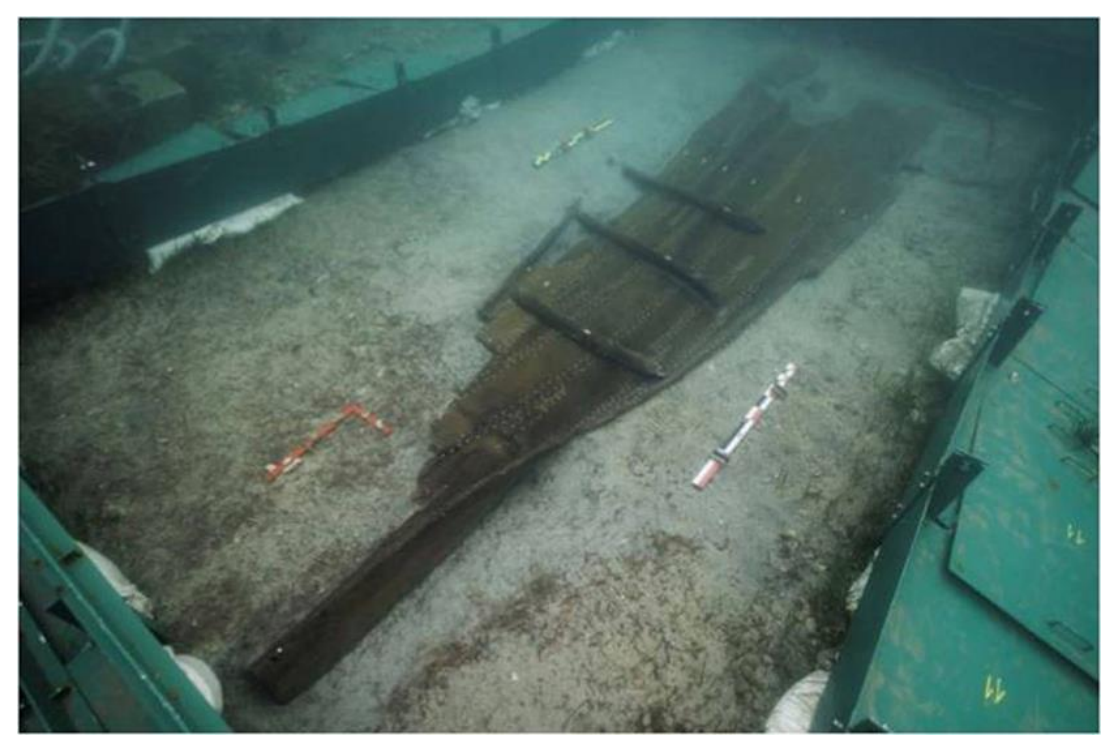

Fig. 2: The Zambratija shipwreck during the 2013 excavation. (@Ph. Groscaux, 2013.AMU/CNRS/CCJ).

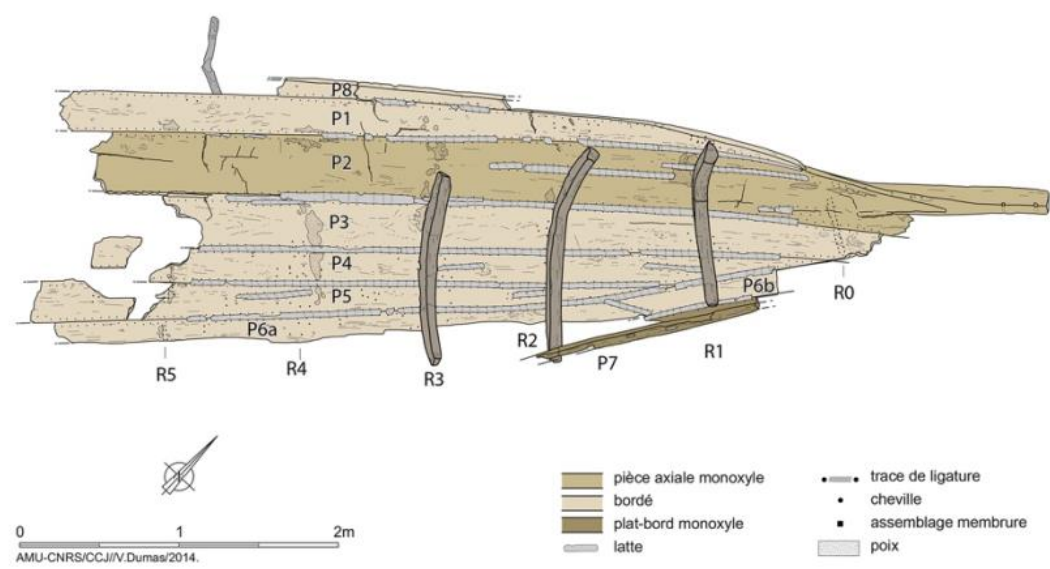

Fig. 3: Planimetry of the shipwreck of Zambratija. (@) V. Dumas, 2014. AMU/CNRS/CCJ). 


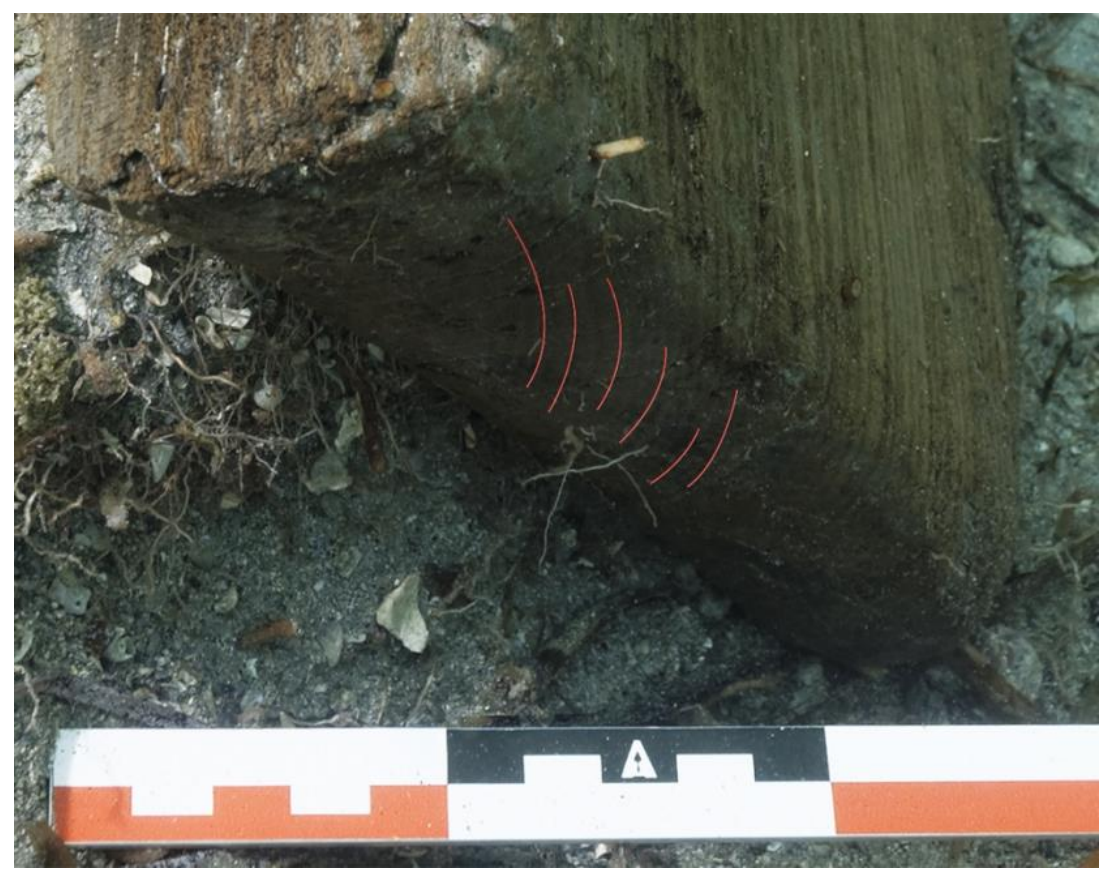

Fig. 4: Zambratija shipwreck. Highlighting of rings on the bow extremity of the keelplank (P2). (@A. Eeckman, 2017).

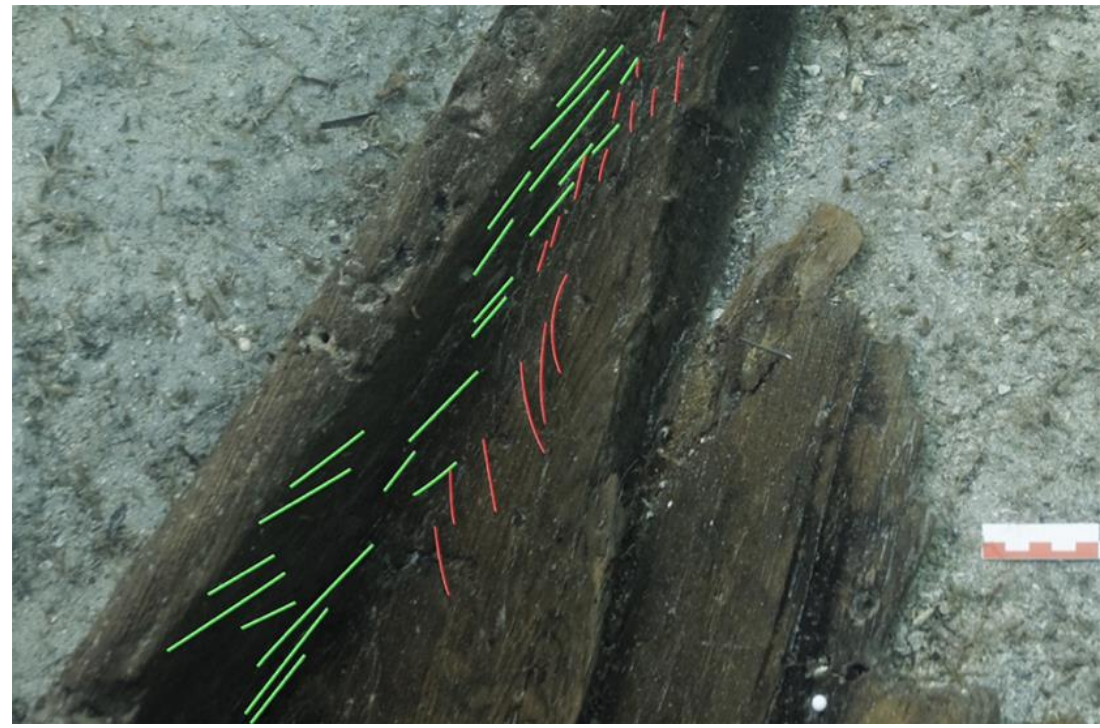

Fig. 5: Zambratija shipwreck. Highlighting of the interior tool marks close to the conserved extremity of P2. (@A. Eeckman, 2017). 


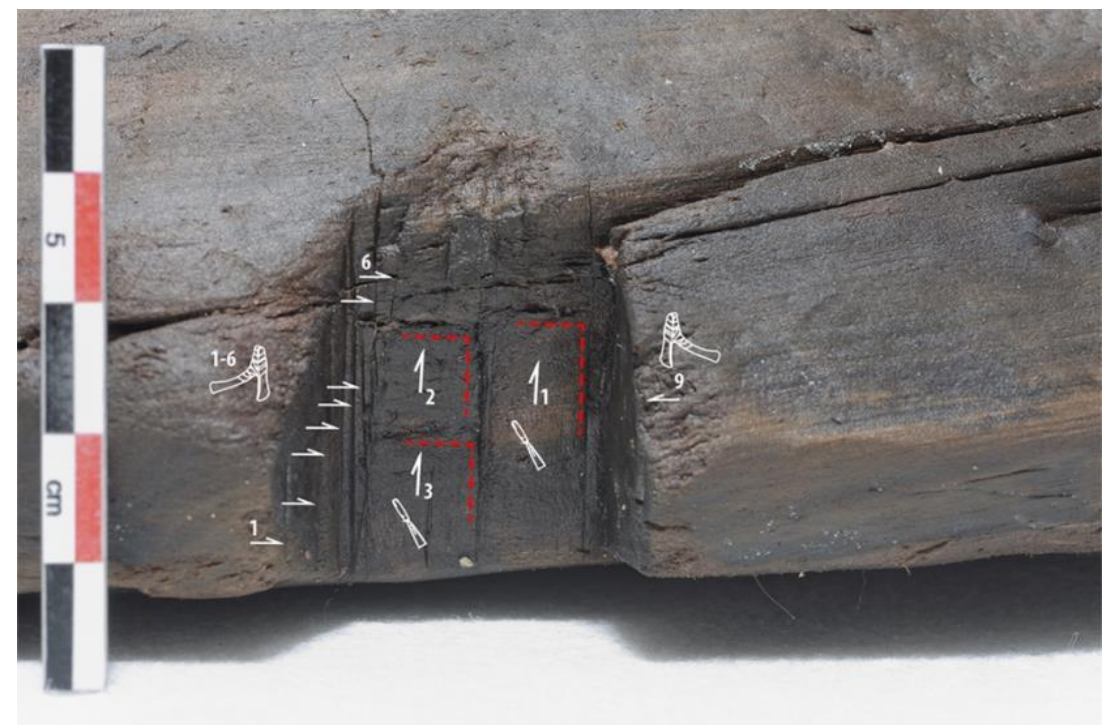

Fig. 6: Zambratija shipwreck. Detail of the limber hole of the floor timber R2 positioned west of the keel plank P2. (@A. Eeckman, 2017).

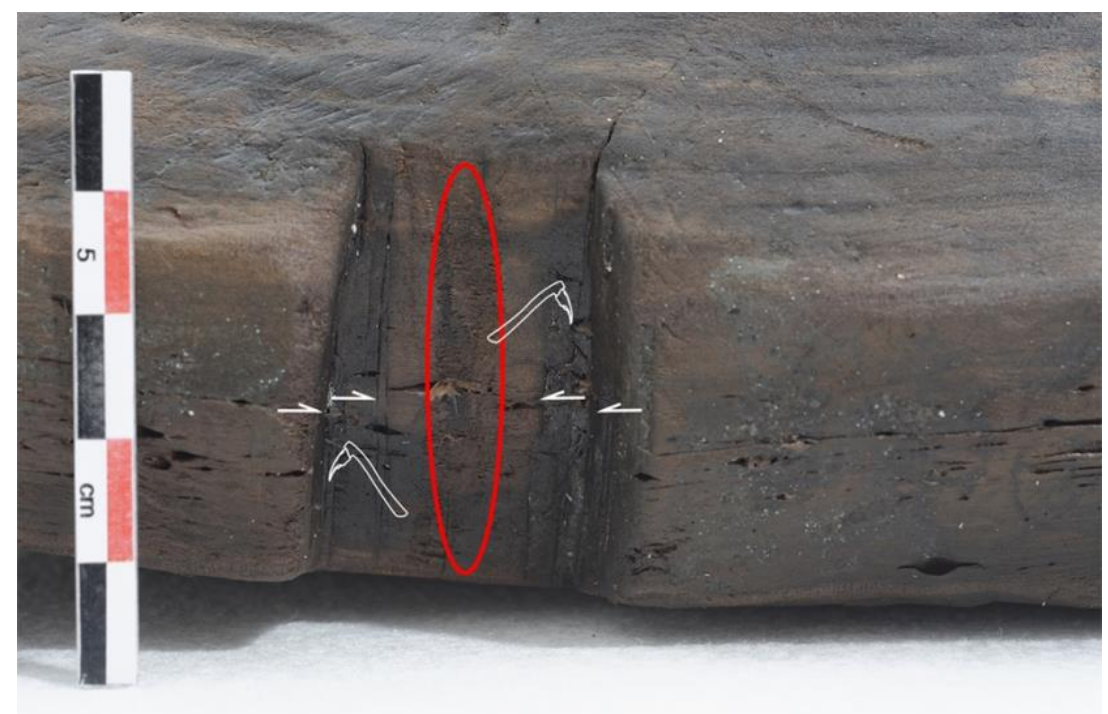

Fig. 7: Zambratija shipwreck. Detail of the limber hole of the floor timber R2 positioned east of the keel plank. (@A. Eeckman, 2017). 


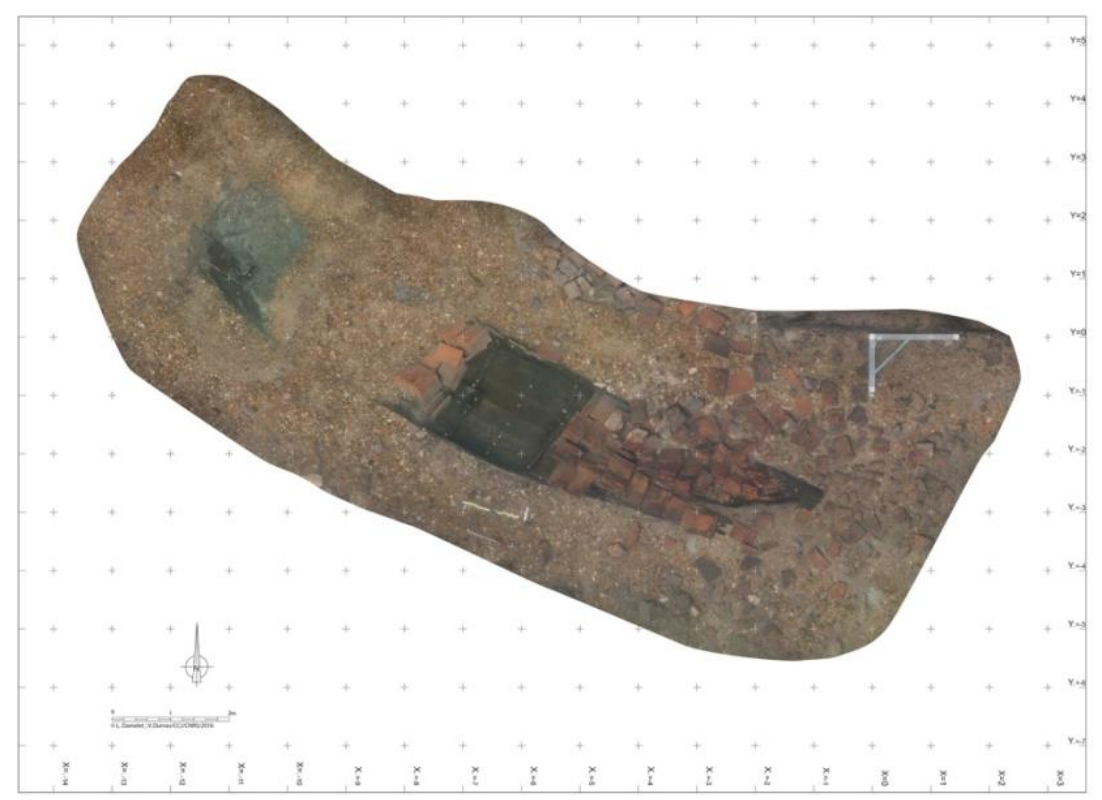

Fig. 8: Orthophotograph of the shipwreck of Kamensko at the end of the 2016 fieldwork.(@ V. Dumas and Loïc Damelet, 2016. AMU/CNRS/CCJ).

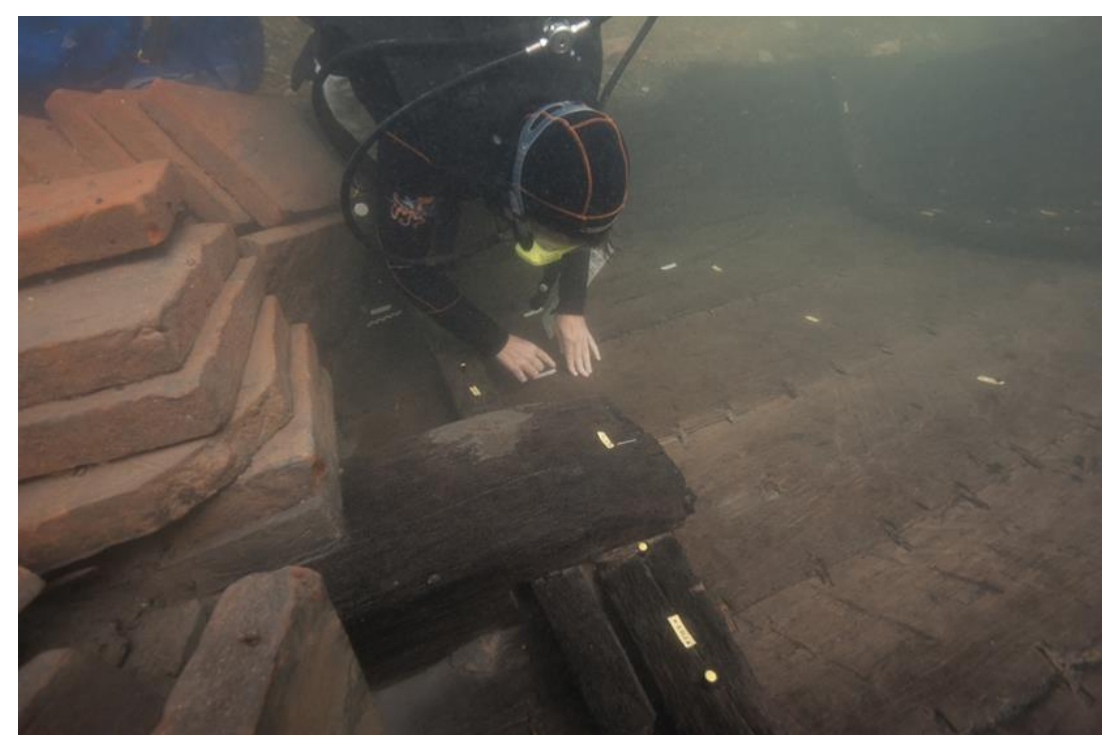

Fig. 9: The exposed hull section of the Kamensko barge in the 2016 trench. From left to right: brick piles, keelson, and strake of the hull with toolmarks. (CL. Damelet, 2016. AMU/CNRS/CCJ). 

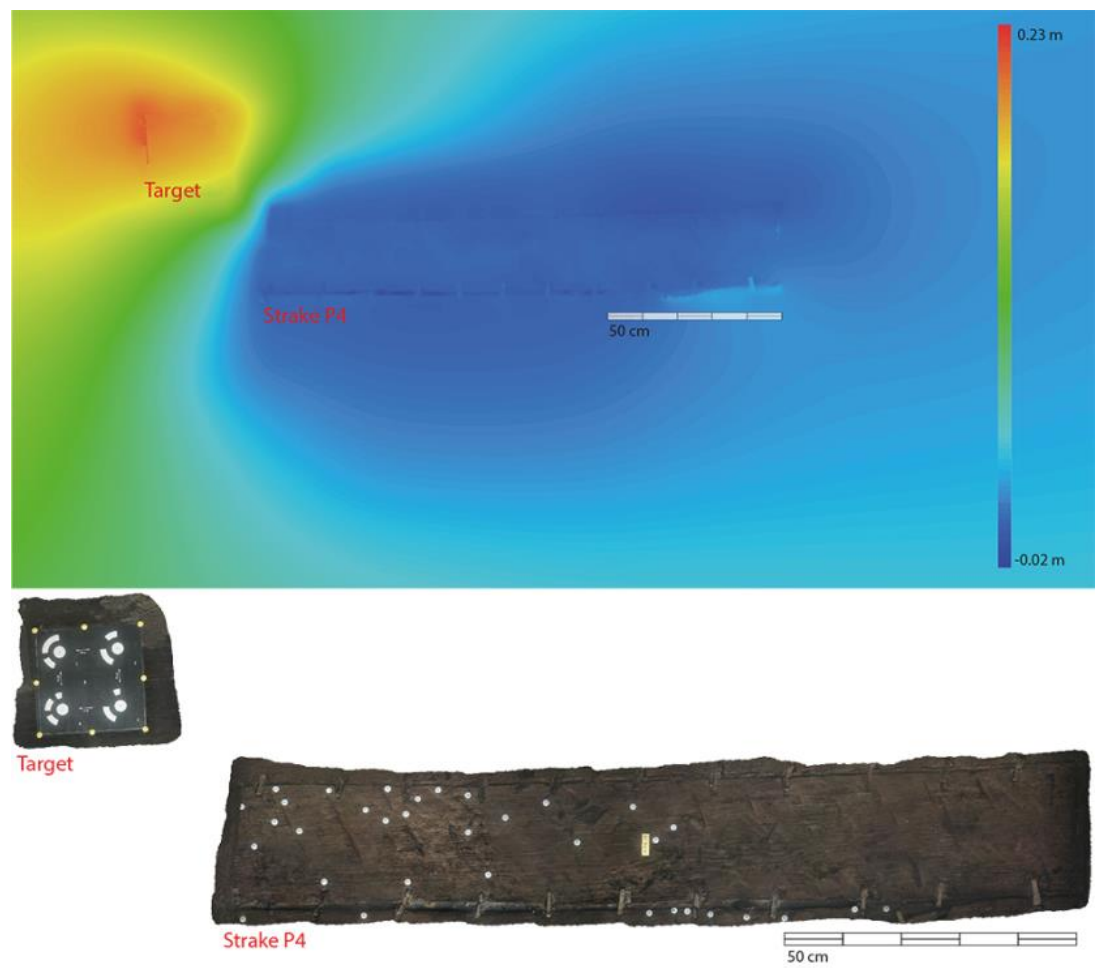

Fig. 10: Kamensko shipwreck. The first digital model and orthophotograph of strake P4 with target. (C) V. Dumas, 2017. AMU/CNRS/CCJ).
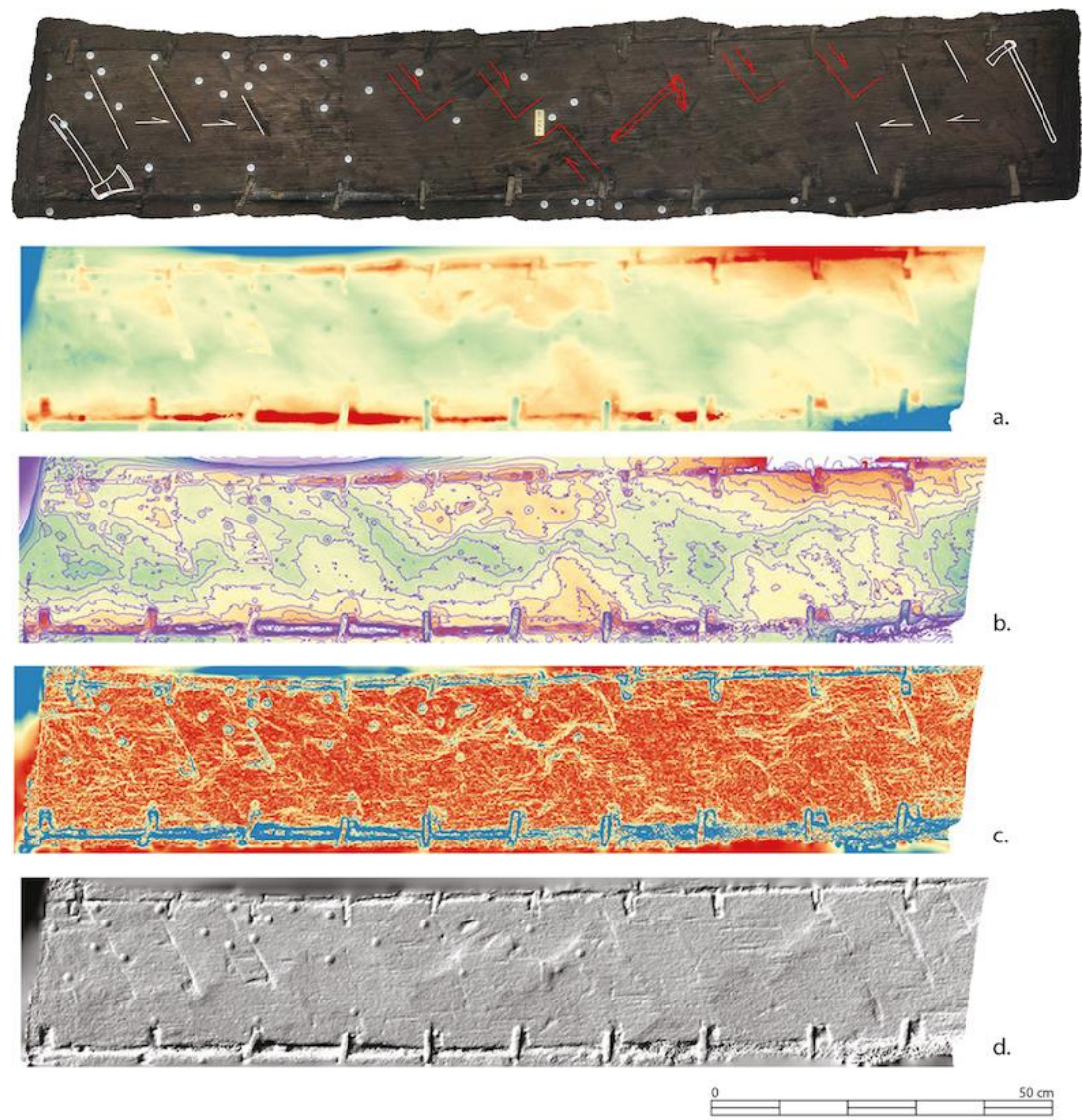
Fig. 11: Orthophotography of strake P4 with drawings of the tools, main toolmarks and the direction of the tool impacts. The white colour refers to the axes and red refers to the adze. From a. to d.: attempts with different filters to highlight the toolmarks. (@A. Eeckman, 2017).

\section{Abbreviations}

AMU : Aix-Marseille Université.

CCJ : Centre Camille Jullian.

CNRS : Centre National de la Recherche Scientifique. 